\title{
An empirical examination of sample size effects on population demographic estimates in birds using single nucleotide polymorphism (SNP) data
}

\author{
Jessica F McLaughlin ${ }^{1,2}$, Kevin Winker ${ }^{\text {Corresp. } 1}$ \\ 1 University of Alaska Museum \& Department of Biology and Wildlife, University of Alaska Fairbanks, Fairbanks, Alaska, USA \\ 2 Sam Noble Oklahoma Museum of Natural History and Department of Biology, University of Oklahoma, Norman, OK, United States \\ Corresponding Author: Kevin Winker \\ Email address: kevin.winker@alaska.edu
}

Sample size is a critical aspect of study design in population genomics research, yet few empirical studies have examined the impacts of small sample sizes. We used datasets from eight diverging bird lineages to make pairwise comparisons at different levels of taxonomic divergence (populations, subspecies, and species). Our data are from loci linked to ultraconserved elements (UCES) and our analyses used one single nucleotide polymorphism ( SNP) per locus. All individuals were genotyped at all loci , effectively doubling sample size for coalescent analyses. We estimated population demographic parameters (effective population size, migration rate, and time since divergence) in a coalescent framework using Diffusion Approximation for Demographic Inference (סаסi), an allele frequency spectrum (AFS) method. Using divergence-with-gene-flow models optimized with full datasets, we subsampled at sequentially smaller sample sizes from full datasets of 6 - 8 diploid individuals per population (with both alleles called) down to 1:1, and then we compared estimates and their changes in accuracy. Accuracy was strongly affected by sample size, with considerable differences among estimated parameters and among lineages. Effective population size parameters $(v)$ tended to be underestimated at low sample sizes (fewer than 3 diploid individuals per population, or 6:6 haplotypes in coalescent terms). Migration $(m)$ was fairly consistently estimated until $<2$ individuals per population, and no consistent trend of over- or underestimation was found in either time since divergence $(T)$ or theta $\left(\Theta=4 N_{\text {ref }} \mu\right)$. Lineages that were taxonomically recognized above the population level (subspecies and species pairs; i.e., deeper divergences) tended to have lower variation in scaled root mean square error (SMRSE) of parameter estimation at smaller sample sizes than population-level divergences, and many parameters were estimated accurately down to 3 diploid individuals per population. Shallower divergence levels (i.e., populations) often required at least 5 individuals per population for reliable demographic inferences using this approach. Although divergence levels might be 
unknown at the outset of study design, our results provide a framework for planning appropriate sampling and for interpreting results if smaller sample sizes must be used. 
1 An empirical examination of sample size effects on population demographic estimates in birds using

2 single nucleotide polymorphism (SNP) data

3

4 Jessica F. McLaughlin ${ }^{1,2}$, Kevin Winker ${ }^{1, *}$

$5{ }^{1}$ University of Alaska Museum \& Department of Biology and Wildlife, 907 Yukon Drive, Fairbanks, AK

699775, USA

72 Sam Noble Oklahoma Museum of Natural History \& Department of Biology, 2401 Chautauqua Ave.,

8 Norman, Oklahoma 73072, USA

$9 \quad{ }^{*}$ Corresponding author: kevin.winker@alaska.edu; 907-474-7027

10

11 


\section{Abstract}

Sample size is a critical aspect of study design in population genomics research, yet few empirical studies have examined the impacts of small sample sizes. We used datasets from eight diverging bird lineages to make pairwise comparisons at different levels of taxonomic divergence (populations, subspecies, and species). Our data are from loci linked to ultraconserved elements (UCEs) and our analyses used one single nucleotide polymorphism (SNP) per locus. All individuals were genotyped at all loci, effectively doubling sample size for coalescent analyses . We estimated population demographic parameters (effective population size, migration rate, and time since divergence) in a coalescent framework using Diffusion Approximation for Demographic Inference ( $\delta a \delta i)$, an allele frequency spectrum (AFS) method. Using divergence-with-gene-flow models optimized with full datasets, we subsampled at sequentially smaller sample sizes from full datasets of $6-8$ diploid individuals per population (with both alleles called) down to 1:1, and then we compared estimates and their changes in accuracy. Accuracy was strongly affected by sample size, with considerable differences among estimated parameters and among lineages. Effective population size parameters $(v)$ tended to be underestimated at low sample sizes (fewer than 3 diploid individuals per population, or 6:6 haplotypes in coalescent terms). Migration $(m)$ was fairly consistently estimated until $\leq 2$ individuals per population, and no consistent trend of over- or underestimation was found in either time since divergence $(T)$ or theta $\left(\Theta=4 N_{\text {ref }} \mu\right)$. Lineages that were taxonomically recognized above the population level (subspecies and species pairs; i.e., deeper divergences) tended to have lower variation in scaled root mean square error (SMRSE) of parameter estimation at smaller sample sizes than population-level divergences, and many parameters were estimated accurately down to 3 diploid individuals per population. Shallower divergence levels (i.e., populations) often required at least 5 individuals per population for reliable demographic inferences using this approach. Although divergence levels might be unknown at the outset of study design, our 


\section{Introduction}

results provide a framework for planning appropriate sampling and for interpreting results if smaller sample sizes must be used.

Genomic-scale data for studying population histories have increased the resolution of demographic estimates, including effective population sizes, migration rates, and times since divergence, even when the number of sampled individuals is relatively low (Willing et al. 2012, Jeffries et al. 2016, Nazareno et al. 2017). However, it is not well understood how the precision and accuracy of these estimates are impacted by lower population sample sizes. The number of individuals that can be included in a study might be limited by practical considerations such as availability of samples for difficult-to-access or endangered populations, tradeoffs between including more individuals per population or more populations, or decisions about whether to include more loci or more individuals (Felsenstein 2005, Pruett \& Winker 2008, Jeffries et al. 2016). Because these issues affect study design, it is important to understand the impacts of relatively low within-population sample sizes on population demographic parameters that are now commonly estimated in a coalescent framework.

The impacts of population sample size, and particularly the tradeoff between increased numbers of individuals versus increased number of loci, has been studied primarily with microsatellite datasets. In general, increasing the number of loci decreases the number of individuals needed for accurate parameter estimations in population genetic studies (Morin et al. 2009, Willing et al. 2012), but different parameter estimates are not impacted uniformly by low sample sizes. A sample size of 8 alleles per population (4:4 diploid individuals) has been suggested as an optimum sample size for obtaining coalescent-based likelihood estimates of theta $\left(\Theta=4 N_{e} \mu\right.$; Felsenstein 2005). This sample size has also been sufficient for non-coalescent-based estimates of unbiased heterozygosity (Pruett \& Winker 2008), which have been effectively estimated with 5-10 individuals. However, other estimators, such as genetic 
diversity (e.g., $A_{E}, H_{O}$, and unbiased $H_{E}$ ) and differentiation $\left(F_{S T}\right)$, require larger sample sizes for accurate estimation, and often the number of individuals required increases as divergence decreases (Kalinowski 2005, Morin et al. 2009).

Modern genomic datasets, with their large numbers of sampled loci, are predicted to decrease the number of individuals required for obtaining accurate estimates of demographic history (Jeffries et al. 2016). However, impacts of sample size on such estimates have undergone only limited investigation thus far, and previous empirical work has focused on estimates of diversity $\left(A_{E}, H_{O}\right.$, and unbiased $\left.H_{E}\right)$ and differentiation ( $F_{\text {ST; }}$ Nazareno et al. 2017). Other demographic estimates made using allele frequency spectrum (AFS) methods have only been evaluated so far with simulated data (Robinson et al. 2014),

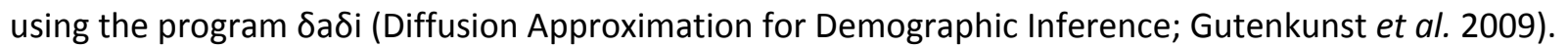
Robinson et al. (2014) showed that median estimated parameter values in two-population $\delta a \delta i$ models of divergence in isolation remained close to true values down to 3 diploid individuals per population. However, this did not hold true across all three model types they examined, and their optimal sampling recommendations depended on the timescale of the demographic events experienced by the populations, with very recent and very ancient events both requiring greater sample sizes (Robinson et al. 2014). In empirical systems, such information on the timescale of demographic events or divergence might be unknown at the outset of a study, particularly in taxa that have not been previously studied, and care must be taken to avoid sampling too few individuals to accurately estimate parameters of interest.

Here we use empirical datasets to conduct pairwise examinations of how inferences of population parameters are impacted by sample size, scaling symmetrically downwards from full datasets that meet or exceed sample sizes widely considered optimal for coalescent-based analyses. We expected that as sample sizes decreased, errors in estimates would increase and accuracy would 
81 decrease, but to varying degrees among parameters, and that systematic biases of mean estimates of

82 parameters might emerge at lower sample sizes. We used empirical datasets from diverging avian

83 lineages with different demographic and evolutionary histories to enhance our understanding of how

84 lower sample sizes affect estimates of effective population size $(v)$, migration $(m)$, time since divergence

$85(T)$, and $\Theta\left(4 N_{\text {ref }} \mu\right)$.

\section{Materials \& Methods}

88

\section{Study system}

We used eight datasets of ultraconserved elements (UCEs) from Beringian birds from McLaughlin et al. (2020; Table 1). Genomic data were generated using the methods outlined in Winker et al. (2019) using protocols from Dr. Travis Glenn's lab at the University of Georgia

(http://baddna.uga.edu/protocols.html). From these data, we generated repeatedly subsampled datasets at smaller sample sizes for analysis under a coalescent framework using Diffusion Approximation for Demographic Inference ( $\delta a \delta i ; ~ G u t e n k u n s t ~ e t ~ a l . ~ 2009)$. While we tried other programs, we were unable to get them to consistently run on our UCE datasets despite months of effort and over a hundred thousand hours of high-performance computing resources (e.g., jaatha, Mathew et al. 2013; IMa2p, Sethuraman \& Hey 2015). Thus, although we lack independent corroboration, we consider $\delta a \delta i$ to be sufficient to answer the questions posed. Our empirical datasets represent taxonomically designated levels of population, subspecies, and species pairs in three avian orders, contrasting pairs of Asian and North American populations of: Clangula hyemalis (long-tailed duck), Anas crecca crecca/A. c. carolinensis (green-winged teal), and Mareca penelope/M. americana (Eurasian and American wigeons) in Anseriformes; Numenius phaeopus variegatus/N. p. hudsonicus (whimbrel), and 
103 Tringa brevipes/T. incana (gray-tailed and wandering tattlers) in Charadriiformes; and Luscinia svecica

104 (bluethroat), Pinicola enucleator kamschatkensis/P. e. flammula (pine grosbeak), and Pica pica/P.

105 hudsonia (Eurasian and black-billed magpies) in Passeriformes. These datasets, which span divergence

106 levels from populations with substantial levels of gene flow to effectively reproductively isolated species

107 (albeit with low gene flow), enable us to explore how the effects of low sample sizes on demographic

108 inference play out across these levels of divergence. Insofar as taxonomy is not a reliable indicator of

109 genomic divergence levels (e.g., Humphries and Winker 2011), we also include in our evaluations

110 estimates of $F_{S T}$ made from the full datasets (Table 1). Among the lineages in this study, pairwise

111 comparisons fell out into two general groups, one with relatively low divergence and one with relatively

112 high divergence (McLaughlin et al. 2020; Table 1).

UCE loci per lineage (each lineage is a pairwise, two-population sample of diverging populations, subspecies, or species). For bioinformatics methods, see Winker et al. (2019) and McLaughlin et al.

116 (2020); a summary of our pipeline is given here: https://github.com/jfmclaughlin92/beringia_scripts.

117 Each dataset consists of 100\% coverage for all individuals (all individuals have phased, high-quality SNPs

118 called at both alleles for all loci). Z-linked loci were removed because they have a different inheritance

119 scalar from autosomal loci (Winker et al. 2019, McLaughlin et al. 2020). Original sequence data are

120 deposited in the NCBI Sequence Read Archive (SRA; PRJNA393740). Complete data files analyzed for this

121 study are available at https://doi.org/10.6084/m9.figshare.12622658.v1 .

\section{Subsampling datasets and analyses}

123 To produce datasets of varying sample sizes, stepping down from the maximum number of individuals

124 available for each population $(6-8)$ to 1 individual per population, a custom Python script

125 (https://github.com/jfmclaughlin92/beringia_scripts) was used. This script (ngapi_dadi.py) iteratively 
126 sampled individuals without replacement from the thinned .vcf files, created new .vcf files containing

127 these individuals, converted these files to the proper $\delta a \delta i$ input format (using a Perl script by Kun Wang,

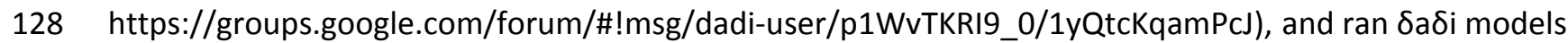

129 with predetermined, lineage-specific best-fit parameters for the split-migration (divergence-with-gene-

130 flow) model that comes with the $\delta a \delta i$ Demographics2D.py file (split-mig). For six of our eight lineages,

131 split-migration models produced a best-fit model among multiple options, while for two of them a

132 secondary contact model was a demonstrably better fit (Clangula hyemalis and Mareca

133 penelope/americana; McLaughlin et al. 2020). Here we chose to include all eight datasets under a single 134 model framework (split-migration, an isolation-with-migration model in $\delta a \delta i$, termed "split-mig"

135 therein). We wished to focus here on changes due to sample size variation with multiple empirical 136 datasets and not on more subtle variation due to differences among divergence-with-gene-flow models.

For each sample size, 25 subsampled datasets were created, which were each run five times.

The best-fit run by highest maximum log composite likelihood (MLCL) value among those five runs was then selected for each dataset and used for subsequent analyses. Parameter estimates for effective population size $\left(v_{1}\right.$ and $\left.v_{2}\right)$, migration $(m)$, divergence time $(T)$, and $\Theta$ (defined as $4 N_{\text {ref }} \mu$, with $N_{\text {ref }}$ defined as ancestral population size and $\mu$ as mutation rate per generation), were then compared across different sample sizes. Raw parameter estimates are used throughout; we did not convert these values to individuals or years (except for three illustrative examples for individuals; see below) because that would introduce lineage-specific idiosyncrasies (e.g., through application of different mutation rate estimates) that would diminish the power of our focal among-lineage comparisons here. For the three exemplar cases in which we translated raw values into numbers of individuals, we used estimates of mutation rate and generation time given in Table S2. 


$$
S R M S E_{\theta}=\frac{\sqrt{\frac{\sum(\hat{\theta}-\theta)^{2}}{n}}}{\underline{\theta}}
$$

150 with $\theta$ in this context representing the estimate from the full dataset, $\hat{\theta}$ as the parameter estimate from

151 the subsampled dataset, and $n$ the number of datasets (25) considered, following Robinson et al. (2014).

152 This was scaled by the mean of the parameter estimate at each sample size $(\underline{\theta})$ to enable inter-lineage

153 comparisons of the changes in accuracy at lower sample sizes (SRMSE). This allowed us to quantify the

154 changes in accuracy of estimates at different sample sizes relative to each species' parameter estimates'

155 means.

\section{Results}

Each lineage had a dataset of between 1,636 and 2,656 variable loci (Table 1). Across the eight lineages,

25 datasets were constructed at each sample size from 1:1 individual up to the full sample size minus one for a total of 1,250 subsampled datasets. smaller sample sizes (Table 2, Figures 1, S1-S5). Performance of mean parameter estimates varied both with lineage and with sample size. The effective population size parameters $\left(v_{1}\right.$ and $\left.v_{2}\right)$ tended to be underestimated at the lowest sample sizes, whereas there was a trend towards overestimation of migration at the lowest sample sizes ( $m$; Table 2, Figures $1, \mathrm{~S} 1-\mathrm{S} 5)$. Divergence time $(T)$ and $\Theta$ were more ambiguous, with both over- and under-estimation occurring in different lineages (Table 2, Figures 1, S1S5). These corresponded in many cases to large changes in the biologically meaningful estimates derived from these parameters. For example, this can be seen in the effective population size parameter of 
170

171

172

173

174

175

176

177

178

179

180

181

182

183

184

185

represents effective population size estimates of 4,478 to 37,410 individuals. In other cases, however, seemingly large changes translated into minor biological differences (e.g., changes in $m$ among pairwise comparisons with very low levels of gene flow, considered in more detail below).

In general, SRMSE increased as sample sizes decreased (Table 3, Figure 2), reflecting the loss of accuracy at lower sample sizes. Lineages with lower levels of divergence (Table 1, Figure S6) tended to exhibit more variability among model runs at higher sample sizes than lineages with higher levels of divergence (e.g., Numenius versus Luscinia in Figure 1 for $v_{2}$ ). This was most notable in the two population-level splits (L. svecica and C. hyemalis; Figures 1, S1-S5). At higher levels of divergence (Table 1)-particularly among T. brevipes/T. incana, N. phaeopus, and Pica pica/Pica hudsonia-most parameter estimates reached a consistent level at approximately 4 or 5 diploid individuals, after which adding more individuals did not considerably improve estimates (Table 2), whereas SRMSE generally only began to increase markedly below $3: 3$ comparisons for population size and split-time estimates (Table 3, Figure 2). In some lower-divergence lineages, such as A. crecca and L. svecica, SRMSE began increasing substantially in most parameters below a sample size of 5 (Table 3, Figure 2). However, this was not universally the case, with SRMSE values in C. hyemalis remaining similar at most sample sizes for multiple parameter estimates (Table 3, Figure 2).

Variation among lineages was noteworthy, as was variation among demographic variables as sample sizes changed. Considering aggregate performance, using SRMSE as the basis for among-lineage contrasts, all lineages showed a significant decrease in performance (increased SRMSE) with smaller sample sizes (Table 4). These relationships were all significant using a linear regression except for the SRMSE of $m$, which showed aberrancies at $N=2$ among some high-divergence lineages (Tables 2,3 , and 4; Figures 2, S6). In many cases the linear regression models were substantially improved by breaking 
192 the lineages into low-divergence and high-divergence groups (groups from Table 1, split by $F_{S T}$ values < 1930.05 and > 0.25; Table S1).

\section{Discussion}

Sample size is an important consideration in study design, but it remains understudied in large-scale genomic datasets (Nazareno et al. 2017). Our results suggest that the minimum reliable sample size will vary considerably from taxon to taxon, depending on factors such as parameters of interest and the depth of the lineage's divergence. Although analyses using coalescent theory have suggested that sample sizes of 8-10 individuals per population are optimal (Felsenstein 2005), by genotyping both alleles of diploid animals our sample sizes were doubled (i.e., $1 N=2$ haplotypes), and we were able to estimate population parameters at considerably lower sample sizes in terms of individuals. Certain parameters, such as migration rate $(m)$ and effective population sizes $\left(v_{1}\right.$, and $\left.v_{2}\right)$, showed fairly consistent patterns of bias in over- or under-estimation across all lineages (Figures 1, S1-S5). In particular, gene flow $(m)$ was fairly consistently estimated with relatively small departures from accuracy down to two individuals per population, after which it was overestimated in all lineages (Table 2; Figure S3).

\section{Estimates of migration}

We found the most variation in estimates of $m$ occuring when samples were at 2:2 (e.g., Pinicola enucleator and Pica pica/hudsonia; Figure 2). In most of the cases in which extreme estimates occurred at 2:2, pairings of individuals that caused geographic clustering of within-continent population samples were involved together with numerically very small estimates of $m$. The values of $m$ were consistently 
214 small, but variation around the mean estimate was apparently magnified by more subtle within-

215 continent variation than our study was designed to detect. Biologically, we reason that small values of $m$

216 are the more informative takeaway, and that increased variation around those very small numbers at $N$

217 of 2:2 is an artifact arising from a combination of relatively deep divergence and very low gene flow,

218 probably coupled with some more subtle population structure within continental populations. In

219 biological terms, although these variations can appear graphically substantial (Figure 2, $m$ ), in Pinicola

220 enucleator they represented estimates ranging ( $\max -\min$ ) from 0.01 to $6.13 \times 10^{-9}$ individuals per

221 generation. In Pica, these max - min values were $0.03-2.29 \times 10^{-9}$ individuals per generation.

222 Estimates of population size

The effective population sizes ( $v$ parameters) were not as robust, with variation tending to begin

to increase markedly below 4 diploid individuals per population and accuracy decreasing in all lineages

225 (Tables 2-3; Figures 1, S1, S2). They were, however, still reasonably accurate in many lineages at

relatively small samples sizes (Tables 2-3; Figures 1, S1, S2). The negative relationships between scaled

root mean square error (SRMSE) values for each demographic parameter and sample size $(N)$ should

help users interpret how lineages and individual parameters are affected by smaller sample sizes (Tables

4, S1).

The impact of divergence under examination. Although this might be known at the start of a study, that might not always be true, potentially complicating sampling design. However, some general recommendations are possible, at least within a broader framework of higher- and lower-divergence groups. Lineages with considerable 
237 lower sample sizes (Figures 2, S1-S5). Thus, it seems possible in such systems to reliably use fewer

238 individuals. In shallowly diverged populations that might experience substantial gene flow, however,

239 higher sample sizes may be required to overcome the impact of individuals with varying amounts of

240 admixture, which appears to increase the variation in model performance at lower sample sizes among

241 low-divergence lineages (Figures 1, S1-S6; Table S1).

accurately estimate population demographic parameters broadly agreed with previous findings in other

more gene flow, greater sample sizes are required to reliably estimate multiple parameters, including

247 (Morin et al. 2009, Humphries \& Winker 2011), and recent demographic events (e.g., < 100 generations;

Beichman et al. 2018). The two population-level splits in our study, L. svecica and C. hyemalis, did not

perform as well for most parameter estimates at sample sizes below 6 individuals per population, with

accuracy (as measured by SRMSE; Table 3) decreasing rapidly; this fits our understanding that accurately estimation.

258 (Gutenkunst et al. 2009) model determined and optimized for the full dataset in each lineage, and we 
260

261

262

263

264

265

266

267

268

269

270

271

272

273

274

275

276

277

278

279

280

281

282

hyemalis, Mareca penelope/M. americana, and Luscinia svecica) showed signs in some parameters of beginning to consistently push the upper bounds of some model parameters. This means that both variation and over-estimation of the parameters were likely underestimated in these groups at smaller sample sizes. This situation has also been noted with simulated data, which have been found in some situations to have a better fit with a model type different than the one under which they were simulated (Robinson et al. 2014).

Implications for study design

Research efficiency requires attention not only to the minimum sample size required to meet an objective, but also to the point after which adding more samples begins to produce diminishing returns.

In this context, this means the point above which the SRMSE becomes similar between sample sizes, but before the means of estimates start to change due to decreased sample size. This inflection point might represent the minimum reliable sample size, but not necessarily. In some lineages, SRMSE was very similar at larger sample sizes, began to slowly increase at intermediate sizes, and then at low sample sizes increased quickly (Table 3, Figure 2). This again varied among lineages (Table 3, Figures S1-S5). In some, such as the Pica and Tringa species lineages, this inflection point was reached at higher sample sizes than the minimum reliable sample sizes in some parameters (Table 3), whereas in others, such as in most estimates of $m$, these points were the same (e.g., Figure S3). However, in some groups, particularly estimates of effective population size $\left(v_{1}\right)$ and migration $(m)$ in $L$. svecica, this optimal point was not reached until the full dataset was analyzed, and might not have been reached at all in $C$. hyemalis in any of the parameter estimates (Figures S1-S5). This is consistent with the findings of Robinson et al. (2014), in that although in some cases a small sample size could be used, larger sample sizes still led to more accurate parameter estimates. This was especially the case in our data for divergence times $(T), \Theta$, and some effective population size $(v)$ estimates (Table 2, Figure 1; Figures S1- 
283 S5). Our linear regression models help generalize these relationships (Tables 4, S1). In sum, two key

284 sources of variation preclude our providing detailed suggestions for threshold sample sizes in future

285 studies: the levels of divergence in a study's focal lineage, and the demographic parameter of most

286 interest for that study. We urge those designing their own studies to consider our results (Tables 2-4,

287 Supplementary Information) at different divergence depths and for different demographic parameters, 288 depending on objectives.

289

290

291

292

293

294

295

296

297

298

299

300

301

302

303

\section{Conclusions}

Sample size is a critical aspect of study design and interpretation, and balancing the need for reliable estimates with cost effectiveness is a key tradeoff. Inadequate sampling can lead to ambiguous or biased results (Nazareno \& Jump 2012, Nazareno et al. 2017), whereas many parameter estimates are not improved above a certain sample size (Felsenstein 2005, Nazareno et al. 2017). As other researchers, we found that inference of demographic parameters can be strongly influenced by sample size, with estimates becoming less accurate at lower sample sizes and being over- and underestimated, with considerable variation both among parameters and among lineages. In general, for pairwise comparisons at shallow levels of divergence (population), care should be taken to include adequate samples, with the best performance in these data generally occurring at 6 or more diploid individuals per population. Parameter estimates in lineages with deeper divergence (subspecies and species) were generally more resilient to lower sample sizes.

\section{Acknowledgements}

The University of Washington Burke Museum provided some specimens for use in this study. Python scripts by Kevin Hawkins were a vital resource in constructing the custom scripts used in this study.

Peer] reviewing PDF | (2020:04:48010:2:0:NEW 19 Aug 2020) 
304 Thanks also to Kathryn Everson, Alexandra Lewis, Naoki Takebayashi, Kris Hundertmark, and two

305 anonymous reviewers for comments on earlier drafts.

306

307

308

309

310

311

312

313

314

315

316

317

318

319

320

321

322

323

324

325

326

327

328

329

330

331

332

333

334

335

336

\section{References}

Adkisson CS (1999) Pine Grosbeak (Pinicola enucleator). In A. F. Poole \& F. B. Gill (Eds.), The Birds of North America. Ithaca, NY, USA: Cornell Lab of Ornithology.

Afgan, E, Baker D, van den Beek M, et al. (2016) The Galaxy platform for accessible, reproducible, and collaborative biomedical analyses: 2016 update. Nucleic Acids Research, 44(W1), W3-W10.

Beichman AC, Huerta-Sanchez E, Lohmueller KE. (2018) Using genomic data to infer historic population dynamics of nonmodel organisms. Annual Review of Ecology, Evolution, and Systematics, 49, 433-56. https://doi.org/10.1146/annurev-ecolsys-110617-062431.

Bolger AM, Lohse M, Usadel B (2014) Trimmomatic: A flexible trimmer for Illumina Sequence Data. Bioinformatics, 30, 2114-2120.

Claramunt S, Cracraft J (2015) A new time tree reveals Earth history's imprint on the evolution of modern birds. Science Advances, 1, e1501005.

Danecek P, Auton A, Abecasis G, et al. (2011) The Variant Call Format and VCFtools. Bioinformatics, 27, 2156-2158.

Faircloth BC (2013) illumiprocessor: a trimmomatic wrapper for parallel adapter and quality trimming. http://dx.doi.org/10.6079/J9ILL.

Faircloth BC (2016) PHYLUCE is a software package for the analysis of conserved genomic loci. Bioinformatics, 32,786-788.

Felsenstein J (2005) Accuracy of coalescent likelihood estimates: do we need more sites, more sequences, or more loci? Molecular Biology and Evolution, 23, 691-700.

Gill RE, McCaffery BJ, Tomkovich PS (2002) Wandering Tattler (Tringa incana). In A. F. Poole \& F. B. Gill (Eds.), The Birds of North America. Ithaca, NY, USA: Cornell Lab of Ornithology.

Grabherr MG, Haas BJ, Yassour M, Levin JZ, Thompson DA, Amit I, Adiconis X, Fan L, Raychowdhury R, Zeng Q, Chen Z, Mauceli E, Hacohen N, Gnirke A, Rhind N, di Palma F, Birren BW, Nusbaum C, Lindblad-Toh K, Friedman N, Regev A (2011) Full-length transcriptome assembly from RNA-seq data without a reference genome. Nature Biotechnology, 29, 644-652. 
337

Gutenkunst RN, Hernandez RD, Williamson SH, Bustamante CD (2009) Inferring the joint demographic history of multiple populations from multidimensional SNP frequency data. PLOS Genetics, 5, e1000695.

Humphries, E. M., \& Winker, K. (2011). Discord reigns among nuclear, mitochondrial and phenotypic estimates of divergence in nine lineages of trans-Beringian birds. Molecular Ecology, 20, 573583.

Jeffries DL, Copp GH, Lawson Handley L, Olsén KH, Sayer CD, Hanfling B (2016) Comparing RADseq and microsatellites to infer complex phylogeographic patterns, an empirical perspective in the Crucian carp, Carassius carassius, L. Molecular Ecology, 25, 2997-3018.

Jombart T, Ahmed I (2011). adegenet 1.3-1: new tools for the analysis of genome-wide SNP data. Bioinformatics, 27, 3070-3071.

Kalinowski ST (2005) Do polymorphic loci require large sample sizes to estimate genetic distances? Heredity, 94, 33-36.

Koskinen MT, Hirvonen H, Landry PA, Primmer CR (2004) The benefits of increasing the number of microsatellites utilized in genetic population studies: an empirical perspective. Hereditas, 141, 61-67.

Li H (2013) Aligning sequence reads, clone sequences and assembly contigs with BWA-MEM. arXiv:1303.3997v1 [q-bio.GN]

Li H, Durbin R (2009) Fast and accurate short read alignment with Burrows-Wheeler transform. Bioinformatics, 25, 1754-1760.

Li H, Handsaker B, Wysoker A, Fennell T, Ruan J, Homer N, Marth G, Abecasis G, Durbin R, 1000 Genome Project Data Processing Subgroup (2009) The sequence alignment/map (SAM) format and SAMtools. Bioinformatics, 25, 2078-2079.

Lischer HEL, Excoffier L (2012) PGDSpider: an automated data conversion tool for connecting population genetics and genomics programs. Bioinformatics, 28, 298-299.

Mathew LA, Staab PR, Rose LE, Metzler D (2013) Why to account for finite sites in population genetic studies and how to do this with jaatha 2.0. Ecology and Evolution, 3, 3647-3662.

McLaughlin JF, Faircloth BC, Glenn TC, Winker K (2020) Divergence, gene flow, and speciation in eight lineages of trans-Beringian birds. Molecular Ecology, https://doi.org/10.1111/mec.15574

McKenna A, Hanna M, Banks E, Sivachenko A, Cibulskis K, Kernytsky A, Garimella K, Altshuler D, Gabriel S, Daly M, DePristo MA (2010) The Genome Analysis Toolkit: a MapReduce framework for analyzing next-generation DNA sequencing data. Genome Research, 20, 1297-1303.

Meirmans PG (2015) Seven common mistakes in population genetics and how to avoid them. Molecular Ecology, 24, 3223-3231.

Morin PA, Martien KK, Taylor BL (2009) Assessing statistical power of SNPs for population structure and conservation studies. Molecular Ecology Resources, 9, 66-73. 
373
Nazareno AG, Jump AS (2012) Species-genetic diversity correlations in habitat fragmentation can be biased by small sample sizes. Molecular Ecology, 21, 2847-2849.

Nazareno AG, Bemmels JB, Dick CW, Lohmann LG (2017) Minimum sample sizes for population genomics: an empirical study from an Amazonian plant species. Molecular Ecology Resources, 17, 1136-1147

Pruett CL, Winker K (2008) The effects of sample size on population genetic diversity estimates in song sparrows Melospiza melodia. Journal of Avian Biology, 39, 252-256.

Robinson JD, Coffman AJ, Hickerson MJ, Gutenkunst RN (2014) Sampling strategies for frequency spectrum-based population genomic inference. BMC Evolutionary Biology, 14, 254-270.

Sethuraman A, Hey J (2015) IMa2p - Parallel MCMC and inference of ancient demography under the isolation with migration (IM) model. Molecular Ecology Resources, 16, 206-215.

Trost CH (1999) Black-billed Magpie (Pica hudsonia). In A. F. Poole \& F. B. Gill (Eds.), The Birds of North America. Ithaca, NY, USA: Cornell Lab of Ornithology.

Willing E-M, Dreyer C, van Oosterhout C (2012) Estimates of genetic differentiation measured by $\mathrm{F}_{\mathrm{ST}}$ do not necessarily require large sample sizes when using many SNP markers. PLOS One, 7, e42649.

Winker K, Glenn TC, Withrow J, Sealy SG, Faircloth BC (2019) Speciation despite gene flow in two owls (Aegolius ssp.): Evidence from 2,517 ultraconserved element loci. Auk, 136, 1-12.

Zhang Z, Schwartz S, Wagner L, Miller W (2000) A greedy algorithm for aligning DNA sequences. Journal of Computational Biology, 7, 203-214. 


\section{Table 1 (on next page)}

Datasets and divergence

Number of variable loci in each lineage, the full dataset size (number of diploid individuals in each population), and $F_{S T}$ values (from McLaughlin et al. 2020). 
1 Table 1: Number of variable loci in each lineage, the full dataset size (number of diploid individuals in

2 each population), and $F_{S T}$ values (from McLaughlin et al. 2020).

3

\begin{tabular}{|c|c|c|c|}
\hline & $\begin{array}{r}\text { Variable } \\
\text { loci }\end{array}$ & $\begin{array}{r}\text { Full } \\
\text { dataset } \\
\text { size }\end{array}$ & $F_{S T}$ \\
\hline \multicolumn{4}{|l|}{ Anseriformes } \\
\hline Clangula hyemalis & 2,442 & $7: 7$ & 0.004 \\
\hline Anas crecca & 2,481 & $6: 6$ & 0.02 \\
\hline $\begin{array}{l}\text { Mareca penelope /M. } \\
\text { americana }\end{array}$ & 2,315 & $8: 8$ & 0.044 \\
\hline \multicolumn{4}{|l|}{ Charadriiformes } \\
\hline Numenius phaeopus & 2,388 & $7: 7$ & 0.269 \\
\hline Tringa brevipes /T. incana & 1,636 & $8: 8$ & 0.585 \\
\hline \multicolumn{4}{|l|}{ Passeriformes } \\
\hline Luscinia svecica & 2,516 & $7: 7$ & 0.014 \\
\hline Pinicola enucleator & 2,656 & $7: 7$ & 0.442 \\
\hline Pica pica/Pica hudsonia & 2,199 & $7: 7$ & 0.328 \\
\hline
\end{tabular}

4 


\section{Table 2 (on next page)}

Demographic parameter estimates

Mean estimates $\left( \pm\right.$ SEM) of effective population size parameters $\left(v_{1}\right.$ and $\left.v_{2}\right)$, migration $(m)$, time since divergence $(T)$, and $\Theta$ (defined as $4 N_{\text {ret }} \mu$, where $N_{\text {ref }}$ is ancestral population size and $\mu$ is mutation rate per generation), in eight lineages of trans-Beringian birds calculated from 25 resampled datasets at each sample size. 
Table 2: Mean estimates ( \pm SEM) of effective population size parameters $\left(v_{1}\right.$ and $\left.v_{2}\right)$, migration $(m)$, time since split $(T)$, and $\Theta\left(\right.$ defined as $4 N_{\text {ref }} \mu$, where $N_{\text {ref }}$ is ancestral population size and $\mu$ is mutation rate per generation), in eight lineages of trans-Beringian birds calculated from 25

3 resampled datasets at each sample size.

\begin{tabular}{|c|c|c|c|c|c|c|c|c|c|}
\hline Anseriformes & Parameter & $8: 8$ & $7: 7$ & $6: 6$ & $5: 5$ & $4: 4$ & $3: 3$ & $2: 2$ & $1: 1$ \\
\hline \multirow[t]{5}{*}{$\begin{array}{l}\text { Clangula } \\
\text { hyemalis }\end{array}$} & $v_{1}$ & - & $\begin{array}{r}8.937 \\
( \pm 1.068)\end{array}$ & $\begin{array}{r}10.706 \\
( \pm 0.449)\end{array}$ & $\begin{array}{r}11.039 \\
( \pm 0.327)\end{array}$ & $\begin{array}{r}10.662 \\
( \pm 0.319)\end{array}$ & $\begin{array}{r}10.977 \\
( \pm 0.234)\end{array}$ & $\begin{array}{r}10.688 \\
( \pm 0.275)\end{array}$ & $\begin{array}{r}8.864 \\
( \pm 0.532)\end{array}$ \\
\hline & $v_{2}$ & - & $\begin{array}{r}6.410 \\
( \pm 1.012)\end{array}$ & $\begin{array}{r}10.704 \\
( \pm 0.255)\end{array}$ & $\begin{array}{r}10.657 \\
( \pm 0.318)\end{array}$ & $\begin{array}{r}10.634 \\
( \pm 0.388)\end{array}$ & $\begin{array}{r}11.546 \\
( \pm 0.130)\end{array}$ & $\begin{array}{r}9.915 \\
( \pm 0.344)\end{array}$ & $\begin{array}{r}9.851 \\
( \pm 0.525)\end{array}$ \\
\hline & $T$ & - & $\begin{array}{r}1.487 \\
( \pm 0.213)\end{array}$ & $\begin{array}{r}1.542 \\
( \pm 0.065)\end{array}$ & $\begin{array}{r}1.460 \\
( \pm 0.067)\end{array}$ & $\begin{array}{r}1.497 \\
( \pm 0.083)\end{array}$ & $\begin{array}{r}1.472 \\
( \pm 0.053)\end{array}$ & $\begin{array}{r}1.639 \\
( \pm 0.105)\end{array}$ & $\begin{array}{r}2.155 \\
( \pm 0.187)\end{array}$ \\
\hline & $m$ & - & $\begin{array}{r}1.217 \\
( \pm 0.229)\end{array}$ & $\begin{array}{r}1.524 \\
( \pm 0.121)\end{array}$ & $\begin{array}{r}1.554 \\
( \pm 0.137)\end{array}$ & $\begin{array}{r}1.704 \\
( \pm 0.148)\end{array}$ & $\begin{array}{r}1.847 \\
( \pm 0.143)\end{array}$ & $\begin{array}{r}2.093 \\
( \pm 0.190)\end{array}$ & $\begin{array}{r}2.324 \\
( \pm 0.157)\end{array}$ \\
\hline & $\Theta$ & - & $\begin{array}{r}204.806 \\
( \pm 33.285)\end{array}$ & $\begin{array}{r}136.062 \\
( \pm 4.133)\end{array}$ & $\begin{array}{r}140.407 \\
( \pm 6.721)\end{array}$ & $\begin{array}{r}139.646 \\
( \pm 6.591)\end{array}$ & $\begin{array}{r}133.497 \\
( \pm 2.999)\end{array}$ & $\begin{array}{r}129.653 \\
( \pm 4.928)\end{array}$ & $\begin{array}{r}116.837 \\
( \pm 6.160)\end{array}$ \\
\hline \multirow[t]{5}{*}{ Anas crecca } & $v_{1}$ & - & - & $\begin{array}{r}13.529 \\
( \pm 0.268)\end{array}$ & $\begin{array}{r}13.515 \\
( \pm 0.229)\end{array}$ & $\begin{array}{r}13.801 \\
( \pm 0.380)\end{array}$ & $\begin{array}{r}12.598 \\
( \pm 0.516)\end{array}$ & $\begin{array}{r}13.261 \\
( \pm 0.526)\end{array}$ & $\begin{array}{r}11.129 \\
( \pm 0.722)\end{array}$ \\
\hline & $v_{2}$ & - & - & $\begin{array}{r}16.737 \\
( \pm 0.450)\end{array}$ & $\begin{array}{r}16.689 \\
( \pm 0.471)\end{array}$ & $\begin{array}{r}16.523 \\
( \pm 0.492)\end{array}$ & $\begin{array}{r}16.939 \\
( \pm 0.516)\end{array}$ & $\begin{array}{r}15.270 \\
( \pm 1.061)\end{array}$ & $\begin{array}{r}11.631 \\
( \pm 1.090)\end{array}$ \\
\hline & $T$ & - & - & $\begin{array}{r}1.154 \\
( \pm 0.039)\end{array}$ & $\begin{array}{r}1.226 \\
( \pm 0.019)\end{array}$ & $\begin{array}{r}1.265 \\
( \pm 0.024)\end{array}$ & $\begin{array}{r}1.333 \\
( \pm 0.045)\end{array}$ & $\begin{array}{r}1.298 \\
( \pm 0.046)\end{array}$ & $\begin{array}{r}1.500 \\
( \pm 0.088)\end{array}$ \\
\hline & $m$ & - & - & $\begin{array}{r}0.736 \\
( \pm 0.063)\end{array}$ & $\begin{array}{r}0.83 \\
( \pm 0.040)\end{array}$ & $\begin{array}{r}0.661 \\
( \pm 0.073)\end{array}$ & $\begin{array}{r}0.699 \\
( \pm 0.114)\end{array}$ & $\begin{array}{r}0.472 \\
( \pm 0.094)\end{array}$ & $\begin{array}{r}0.765 \\
( \pm 0.147)\end{array}$ \\
\hline & $\Theta$ & - & - & 143.00 & 135.50 & 133.17 & 130.67 & 133.51 & 127.13 \\
\hline
\end{tabular}


$( \pm 4.157)$

$( \pm 1.492) \quad( \pm 1.581)$

$( \pm 3.204)$

$( \pm 2.831)$

$( \pm 5.231)$ 
Table 2, cont.

Mareca penelope/A.

americana

Charadriiformes Numenius phaeopus

Parameter

$$
\text { 8:8 }
$$

7:7

$6: 6$ $5: 5$

4:4

3:3

$2: 2$ 1:1

\begin{tabular}{|c|c|c|c|c|c|c|c|c|}
\hline$v_{1}$ & $\begin{array}{r}10.116 \\
( \pm 0.002)\end{array}$ & $\begin{array}{r}10.518 \\
( \pm 0.132)\end{array}$ & $\begin{array}{r}9.847 \\
( \pm 0.318)\end{array}$ & $\begin{array}{r}10.063 \\
( \pm 0.217)\end{array}$ & $\begin{array}{r}9.904 \\
( \pm 0.260)\end{array}$ & $\begin{array}{r}9.398 \\
( \pm 0.320)\end{array}$ & $\begin{array}{r}10.193 \\
( \pm 0.466)\end{array}$ & $\begin{array}{r}9.438 \\
( \pm 0.618)\end{array}$ \\
\hline$v_{2}$ & $\begin{array}{r}15.608 \\
( \pm 0.004)\end{array}$ & $\begin{array}{r}15.147 \\
( \pm 0.192)\end{array}$ & $\begin{array}{r}14.895 \\
( \pm 0.237)\end{array}$ & $\begin{array}{r}14.531 \\
( \pm 0.334)\end{array}$ & $\begin{array}{r}14.082 \\
( \pm 0.302)\end{array}$ & $\begin{array}{r}14.015 \\
( \pm 0.535)\end{array}$ & $\begin{array}{r}12.644 \\
( \pm 0.562)\end{array}$ & $\begin{array}{r}6.276 \\
( \pm 0.713)\end{array}$ \\
\hline$T$ & $\begin{array}{r}1.139 \\
( \pm 0.000)\end{array}$ & $\begin{array}{r}1.135 \\
( \pm 0.023)\end{array}$ & $\begin{array}{r}1.209 \\
( \pm 0.035)\end{array}$ & $\begin{array}{r}1.190 \\
( \pm 0.021)\end{array}$ & $\begin{array}{r}1.214 \\
( \pm 0.023)\end{array}$ & $\begin{array}{r}1.235 \\
( \pm 0.036)\end{array}$ & $\begin{array}{r}1.268 \\
( \pm 0.043)\end{array}$ & $\begin{array}{r}1.267 \\
( \pm 0.077)\end{array}$ \\
\hline$m$ & $\begin{array}{r}0.704 \\
( \pm 0.000)\end{array}$ & $\begin{array}{r}0.750 \\
( \pm 0.095)\end{array}$ & $\begin{array}{r}0.644 \\
( \pm 0.021)\end{array}$ & $\begin{array}{r}0.654 \\
( \pm 0.028)\end{array}$ & $\begin{array}{r}0.716 \\
( \pm 0.049)\end{array}$ & $\begin{array}{r}0.529 \\
( \pm 0.062)\end{array}$ & $\begin{array}{r}0.568 \\
( \pm 0.093)\end{array}$ & $\begin{array}{r}1.761 \\
( \pm 0.247)\end{array}$ \\
\hline$\theta$ & $\begin{array}{r}128.06 \\
( \pm 0.012)\end{array}$ & $\begin{array}{r}128.83 \\
( \pm 1.794)\end{array}$ & $\begin{array}{r}125.16 \\
( \pm 1.024)\end{array}$ & $\begin{array}{r}125.08 \\
( \pm 1.178)\end{array}$ & $\begin{array}{r}123.56 \\
( \pm 1.177)\end{array}$ & $\begin{array}{r}123.76 \\
( \pm 1.912)\end{array}$ & $\begin{array}{r}121.81 \\
( \pm 1.946)\end{array}$ & $\begin{array}{r}128.64 \\
( \pm 4.026)\end{array}$ \\
\hline$T$ & - & $\begin{array}{r}1.968 \\
( \pm 0.002)\end{array}$ & $\begin{array}{r}1.931 \\
( \pm 0.019)\end{array}$ & $\begin{array}{r}1.981 \\
( \pm 0.027)\end{array}$ & $\begin{array}{r}1.894 \\
( \pm 0.040)\end{array}$ & $\begin{array}{r}1.796 \\
( \pm 0.063)\end{array}$ & $\begin{array}{r}1.501 \\
( \pm 0.052)\end{array}$ & $\begin{array}{r}2.386 \\
( \pm 0.132)\end{array}$ \\
\hline$m$ & - & $\begin{array}{r}0.056 \\
( \pm 0.000)\end{array}$ & $\begin{array}{r}0.055 \\
( \pm 0.001)\end{array}$ & $\begin{array}{r}0.056 \\
( \pm 0.001)\end{array}$ & $\begin{array}{r}0.052 \\
( \pm 0.003)\end{array}$ & $\begin{array}{r}0.042 \\
( \pm 0.004)\end{array}$ & $\begin{array}{r}0.023 \\
( \pm 0.007)\end{array}$ & $\begin{array}{r}0.133 \\
( \pm 0.013)\end{array}$ \\
\hline
\end{tabular}




\begin{tabular}{|c|c|c|c|c|c|c|c|c|c|}
\hline Table 2 , cont. & Parameter & $8: 8$ & $7: 7$ & $6: 6$ & $5: 5$ & $4: 4$ & $3: 3$ & $2: 2$ & 1:1 \\
\hline \multirow{5}{*}{$\begin{array}{l}\text { Tringa } \\
\text { brevipes/T. } \\
\text { incana }\end{array}$} & $v_{1}$ & $\begin{array}{r}7.894 \\
( \pm 0.135)\end{array}$ & $\begin{array}{r}8.487 \\
( \pm 0.093)\end{array}$ & $\begin{array}{r}7.516 \\
( \pm 0.166)\end{array}$ & $\begin{array}{r}7.014 \\
( \pm 0.223)\end{array}$ & $\begin{array}{r}6.382 \\
( \pm 0.267)\end{array}$ & $\begin{array}{r}5.258 \\
( \pm 0.625)\end{array}$ & $\begin{array}{r}2.806 \\
( \pm 0.292)\end{array}$ & $\begin{array}{r}1.016 \\
( \pm 0.086)\end{array}$ \\
\hline & $v_{2}$ & $\begin{array}{r}2.559 \\
( \pm 0.045)\end{array}$ & $\begin{array}{r}2.835 \\
( \pm 0.036)\end{array}$ & $\begin{array}{r}2.663 \\
( \pm 0.055)\end{array}$ & $\begin{array}{r}2.537 \\
( \pm 0.085)\end{array}$ & $\begin{array}{r}2.613 \\
( \pm 0.103)\end{array}$ & $\begin{array}{r}2.395 \\
( \pm 0.111)\end{array}$ & $\begin{array}{r}1.416 \\
( \pm 0.150)\end{array}$ & $\begin{array}{r}0.578 \\
( \pm 0.050)\end{array}$ \\
\hline & $T$ & $\begin{array}{r}6.575 \\
( \pm 0.134)\end{array}$ & $\begin{array}{r}7.624 \\
( \pm 0.107)\end{array}$ & $\begin{array}{r}7.284 \\
( \pm 0.189)\end{array}$ & $\begin{array}{r}7.153 \\
( \pm 0.291)\end{array}$ & $\begin{array}{r}7.542 \\
( \pm 0.364)\end{array}$ & $\begin{array}{r}7.033 \\
( \pm 0.389)\end{array}$ & $\begin{array}{r}3.856 \\
( \pm 0.536)\end{array}$ & $\begin{array}{r}1.942 \\
( \pm 0.203)\end{array}$ \\
\hline & $m$ & $\begin{array}{r}0.0091 \\
( \pm 0.000)\end{array}$ & $\begin{array}{r}0.0081 \\
( \pm 0.000)\end{array}$ & $\begin{array}{r}0.0084 \\
( \pm 0.000)\end{array}$ & $\begin{array}{r}0.0085 \\
( \pm 0.000)\end{array}$ & $\begin{array}{r}0.0090 \\
( \pm 0.000)\end{array}$ & $\begin{array}{r}0.0098 \\
( \pm 0.000)\end{array}$ & $\begin{array}{r}0.008 \\
( \pm 0.002)\end{array}$ & $\begin{array}{r}0.165 \\
( \pm 0.015)\end{array}$ \\
\hline & $\Theta$ & $\begin{array}{r}56.345 \\
( \pm 0.986)\end{array}$ & $\begin{array}{r}49.828 \\
( \pm 0.628)\end{array}$ & $\begin{array}{r}52.707 \\
( \pm 1.250)\end{array}$ & $\begin{array}{r}54.627 \\
( \pm 2.022)\end{array}$ & $\begin{array}{r}53.799 \\
( \pm 2.686)\end{array}$ & $\begin{array}{r}58.978 \\
( \pm 4.510)\end{array}$ & $\begin{array}{r}113.161 \\
( \pm 10.291)\end{array}$ & $\begin{array}{r}117.030 \\
( \pm 8.657)\end{array}$ \\
\hline \multirow[t]{5}{*}{$\begin{array}{l}\text { Passeriformes } \\
\quad \text { Luscinia svecica }\end{array}$} & $v_{1}$ & - & $\begin{array}{r}3.877 \\
( \pm 0.005)\end{array}$ & $\begin{array}{r}3.934 \\
( \pm 0.089)\end{array}$ & $\begin{array}{r}4.618 \\
( \pm 0.344)\end{array}$ & $\begin{array}{r}5.056 \\
( \pm 0.408)\end{array}$ & $\begin{array}{r}5.827 \\
( \pm 0.435)\end{array}$ & $\begin{array}{r}6.322 \\
( \pm 0.488)\end{array}$ & $\begin{array}{r}5.452 \\
( \pm 0.403)\end{array}$ \\
\hline & $v_{2}$ & - & $\begin{array}{r}21.452 \\
( \pm 0.092)\end{array}$ & $\begin{array}{r}20.980 \\
( \pm 0.442)\end{array}$ & $\begin{array}{r}18.847 \\
( \pm 0.961)\end{array}$ & $\begin{array}{r}15.954 \\
( \pm 1.072)\end{array}$ & $\begin{array}{r}15.795 \\
( \pm 1.156)\end{array}$ & $\begin{array}{r}14.675 \\
( \pm 1.307)\end{array}$ & $\begin{array}{r}15.969 \\
( \pm 1.432)\end{array}$ \\
\hline & $T$ & - & $\begin{array}{r}1.290 \\
( \pm 0.003)\end{array}$ & $\begin{array}{r}1.285 \\
( \pm 0.015)\end{array}$ & $\begin{array}{r}1.276 \\
( \pm 0.031)\end{array}$ & $\begin{array}{r}1.243 \\
( \pm 0.063)\end{array}$ & $\begin{array}{r}1.226 \\
( \pm 0.043)\end{array}$ & $\begin{array}{r}1.203 \\
( \pm 0.067)\end{array}$ & $\begin{array}{r}1.256 \\
( \pm 0.104)\end{array}$ \\
\hline & $m$ & - & $\begin{array}{r}1.956 \\
( \pm 0.058)\end{array}$ & $\begin{array}{r}2.122 \\
( \pm 0.108)\end{array}$ & $\begin{array}{r}2.127 \\
( \pm 0.245)\end{array}$ & $\begin{array}{r}2.330 \\
( \pm 0.347)\end{array}$ & $\begin{array}{r}3.357 \\
( \pm 0.334)\end{array}$ & $\begin{array}{r}2.416 \\
( \pm 0.332)\end{array}$ & $\begin{array}{r}2.940 \\
( \pm 0.312)\end{array}$ \\
\hline & $\theta$ & - & $\begin{array}{r}166.94 \\
( \pm 0.176)\end{array}$ & $\begin{array}{r}167.608 \\
( \pm 1.033)\end{array}$ & $\begin{array}{r}167.935 \\
( \pm 2.405)\end{array}$ & $\begin{array}{r}176.558 \\
( \pm 5.360)\end{array}$ & $\begin{array}{r}172.299 \\
( \pm 3.636)\end{array}$ & $\begin{array}{r}175.525 \\
( \pm 4.166)\end{array}$ & $\begin{array}{r}180.675 \\
( \pm 8.488)\end{array}$ \\
\hline
\end{tabular}




\begin{tabular}{|c|c|c|c|c|c|c|c|c|c|}
\hline Table 2, cont. & Parameter & $8: 8$ & 7:7 & $6: 6$ & $5: 5$ & $4: 4$ & $3: 3$ & $2: 2$ & $1: 1$ \\
\hline \multirow[t]{5}{*}{$\begin{array}{l}\text { Pinicola } \\
\text { enucleator }\end{array}$} & $v_{1}$ & - & $\begin{array}{r}2.519 \\
( \pm 0.016)\end{array}$ & $\begin{array}{r}2.846 \\
( \pm 0.057)\end{array}$ & $\begin{array}{r}2.843 \\
( \pm 0.076)\end{array}$ & $\begin{array}{r}2.658 \\
( \pm 0.113)\end{array}$ & $\begin{array}{r}2.597 \\
( \pm 0.120)\end{array}$ & $\begin{array}{r}2.197 \\
( \pm 0.121)\end{array}$ & $\begin{array}{r}2.325 \\
( \pm 0.117)\end{array}$ \\
\hline & $v_{2}$ & - & $\begin{array}{r}1.786 \\
( \pm 0.011)\end{array}$ & $\begin{array}{r}2.355 \\
( \pm 0.013)\end{array}$ & $\begin{array}{r}2.112 \\
( \pm 0.046)\end{array}$ & $\begin{array}{r}1.898 \\
( \pm 0.063)\end{array}$ & $\begin{array}{r}1.656 \\
( \pm 0.050)\end{array}$ & $\begin{array}{r}1.412 \\
( \pm 0.037)\end{array}$ & $\begin{array}{r}1.465 \\
( \pm 0.073)\end{array}$ \\
\hline & $T$ & - & $\begin{array}{r}1.979 \\
( \pm 0.021)\end{array}$ & $\begin{array}{r}2.449 \\
( \pm 0.028)\end{array}$ & $\begin{array}{r}2.317 \\
( \pm 0.076)\end{array}$ & $\begin{array}{r}2.098 \\
( \pm 0.099)\end{array}$ & $\begin{array}{r}1.866 \\
( \pm 0.077)\end{array}$ & $\begin{array}{r}1.568 \\
( \pm 0.048)\end{array}$ & $\begin{array}{r}2.480 \\
( \pm 0.184)\end{array}$ \\
\hline & $m$ & - & $\begin{array}{r}0.0073 \\
( \pm 0.001)\end{array}$ & $\begin{array}{r}0.0105 \\
( \pm 0.000)\end{array}$ & $\begin{array}{r}0.0107 \\
( \pm 0.001)\end{array}$ & $\begin{array}{r}0.00677 \\
( \pm 0.001)\end{array}$ & $\begin{array}{r}0.0033 \\
( \pm 0.001)\end{array}$ & $\begin{array}{r}0.0010 \\
( \pm 0.001)\end{array}$ & $\begin{array}{r}0.0596 \\
( \pm 0.004)\end{array}$ \\
\hline & $\Theta$ & - & $\begin{array}{r}223.76 \\
( \pm 1.51)\end{array}$ & $\begin{array}{r}197.10 \\
( \pm 1.41)\end{array}$ & $\begin{array}{r}205.45 \\
( \pm 3.30)\end{array}$ & $\begin{array}{r}219.25 \\
( \pm 5.23)\end{array}$ & $\begin{array}{r}233.07 \\
( \pm 5.22)\end{array}$ & $\begin{array}{r}256.52 \\
( \pm 4.80)\end{array}$ & $\begin{array}{r}212.34 \\
( \pm 11.87)\end{array}$ \\
\hline \multirow[t]{5}{*}{$\begin{array}{l}\text { Pica pica/Pica } \\
\text { hudsonia }\end{array}$} & $v_{1}$ & - & $\begin{array}{r}2.699 \\
( \pm 0.042)\end{array}$ & $\begin{array}{r}2.485 \\
( \pm 0.046)\end{array}$ & $\begin{array}{r}2.406 \\
( \pm 0.057)\end{array}$ & $\begin{array}{r}2.298 \\
( \pm 0.075)\end{array}$ & $\begin{array}{r}2.300 \\
( \pm 0.094)\end{array}$ & $\begin{array}{r}2.117 \\
( \pm 0.142)\end{array}$ & $\begin{array}{r}1.567 \\
( \pm 0.144)\end{array}$ \\
\hline & $v_{2}$ & - & $\begin{array}{r}7.107 \\
( \pm 0.126)\end{array}$ & $\begin{array}{r}6.759 \\
( \pm 0.225)\end{array}$ & $\begin{array}{r}6.470 \\
( \pm 0.330)\end{array}$ & $\begin{array}{r}6.604 \\
( \pm 0.390)\end{array}$ & $\begin{array}{r}6.565 \\
( \pm 0.501)\end{array}$ & $\begin{array}{r}5.537 \\
( \pm 0.528)\end{array}$ & $\begin{array}{r}3.029 \\
( \pm 0.587)\end{array}$ \\
\hline & $T$ & - & $\begin{array}{r}3.334 \\
( \pm 0.069)\end{array}$ & $\begin{array}{r}3.017 \\
( \pm 0.046)\end{array}$ & $\begin{array}{r}2.868 \\
( \pm 0.067)\end{array}$ & $\begin{array}{r}2.710 \\
( \pm 0.089)\end{array}$ & $\begin{array}{r}2.561 \\
( \pm 0.114)\end{array}$ & $\begin{array}{r}2.325 \\
( \pm 0.143)\end{array}$ & $\begin{array}{r}2.309 \\
( \pm 0.190)\end{array}$ \\
\hline & $m$ & - & $\begin{array}{r}0.0141 \\
( \pm 0.000)\end{array}$ & $\begin{array}{r}0.0121 \\
( \pm 0.000)\end{array}$ & $\begin{array}{r}0.0119 \\
( \pm 0.010)\end{array}$ & $\begin{array}{r}0.0086 \\
( \pm 0.001)\end{array}$ & $\begin{array}{r}0.0066 \\
( \pm 0.001)\end{array}$ & $\begin{array}{r}0.0033 \\
( \pm 0.001)\end{array}$ & $\begin{array}{r}0.0808 \\
( \pm 0.012)\end{array}$ \\
\hline & $\Theta$ & - & $\begin{array}{r}108.09 \\
( \pm 1.602)\end{array}$ & $\begin{array}{r}116.50 \\
( \pm 1.48)\end{array}$ & $\begin{array}{r}121.01 \\
( \pm 2.00)\end{array}$ & $\begin{array}{r}126.62 \\
( \pm 3.26)\end{array}$ & $\begin{array}{r}132.95 \\
( \pm 4.74)\end{array}$ & $\begin{array}{r}146.85 \\
( \pm 7.58)\end{array}$ & $\begin{array}{r}162.11 \\
( \pm 9.71)\end{array}$ \\
\hline
\end{tabular}




\section{Table 3(on next page)}

Scaled root mean square errors

Scaled root mean square error (SRMSE) for each parameter at each diminished sample size. Parameters are effective population size $\left(v_{1}\right.$ and $\left.v_{2}\right)$, migration $(m)$, time since divergence $(T)$, and $\Theta$ (defined as $4 N_{\text {ref }} \mu$, where $N_{\text {ref }}$ is ancestral population size and $\mu$ is mutation rate per generation). 
Table 3: Scaled root mean square error (SRMSE) for each parameter at each diminished sample size. Parameters are effective population size $\left(v_{1}\right.$ and $v_{2}$ ), migration $(m)$, time since split $(T)$, and $\Theta$ (defined as $4 N_{r e} \mu$, where $N_{\text {ref }}$ is ancestral population size and $\mu$ is mutation rate per generation).

3

\begin{tabular}{|c|c|c|c|c|c|c|c|c|}
\hline & Parameter & $7: 7$ & $6: 6$ & $5: 5$ & $4: 4$ & $3: 3$ & $2: 2$ & $1: 1$ \\
\hline & & 7 & 6 & 5 & 4 & 3 & 2 & 1 \\
\hline Clangula hyemalis & $m$ & & 0.391 & 0.438 & 0.451 & 0.436 & 0.540 & 0.500 \\
\hline Anas crecca & $m$ & & & 0.262 & 0.556 & 0.803 & 1.123 & 0.942 \\
\hline Mareca penelope/M. americana & $m$ & 0.624 & 0.187 & 0.221 & 0.339 & 0.661 & 0.838 & 0.913 \\
\hline Numenius phaeopus & $m$ & & 0.082 & 0.128 & 0.330 & 0.627 & 2.026 & 0.753 \\
\hline Tringa brevipes/T. incana & $m$ & 1.293 & 1.213 & 1.214 & 1.081 & 0.928 & 1.659 & 0.992 \\
\hline Luscinia svecica & $m$ & & 0.262 & 0.570 & 0.747 & 0.642 & 0.699 & 0.619 \\
\hline Pinicola enucleator & $m$ & & 2.809 & 2.779 & 5.003 & 11.108 & 38.261 & 0.486 \\
\hline \multirow[t]{2}{*}{ Pica pica/Pica hudsonia } & $m$ & & 0.650 & 0.771 & 1.459 & 2.182 & 5.303 & 1.053 \\
\hline & & 7 & 6 & 5 & 4 & 3 & 2 & 1 \\
\hline Clangula hyemalis & $v_{1}$ & & 0.225 & 0.156 & 0.174 & 0.122 & 0.156 & 0.432 \\
\hline Anas crecca & $v_{1}$ & & & 0.081 & 0.136 & 0.214 & 0.195 & 0.384 \\
\hline Mareca penelope/M. americana & $v_{1}$ & 0.073 & 0.161 & 0.106 & 0.130 & 0.183 & 0.224 & 0.329 \\
\hline Numenius phaeopus & $v_{1}$ & & 0.049 & 0.069 & 0.109 & 0.163 & 0.299 & 0.318 \\
\hline Tringa brevipes/T. incana & $v_{1}$ & 0.116 & 0.109 & 0.178 & 0.282 & 0.512 & 1.788 & 6.511 \\
\hline Luscinia svecica & $v_{1}$ & & 0.112 & 0.398 & 0.459 & 0.496 & 0.541 & 0.464 \\
\hline Pinicola enucleator & $v_{1}$ & & 0.141 & 0.167 & 0.275 & 0.307 & 0.505 & 0.427 \\
\hline \multirow[t]{2}{*}{ Pica pica/Pica hudsonia } & $v_{1}$ & & 0.157 & 0.202 & 0.271 & 0.296 & 0.462 & 0.907 \\
\hline & & 7 & 6 & 5 & 4 & 3 & 2 & 1 \\
\hline Clangula hyemalis & $v_{2}$ & & 0.141 & 0.164 & 0.193 & 0.156 & 0.170 & 0.261 \\
\hline Anas crecca & $v_{2}$ & & & 0.138 & 0.146 & 0.150 & 0.354 & 0.635 \\
\hline Mareca penelope/M. americana & $v_{2}$ & 0.069 & 0.091 & 0.135 & 0.151 & 0.217 & 0.320 & 1.588 \\
\hline Numenius phaeopus & $v_{2}$ & & 0.059 & 0.061 & 0.122 & 0.198 & 0.345 & 0.554 \\
\hline Tringa brevipes/T. incana & $v_{2}$ & 0.154 & 0.133 & 0.168 & 0.204 & 0.228 & 0.887 & 3.241 \\
\hline Luscinia svecica & $v_{2}$ & & 0.106 & 0.285 & 0.477 & 0.507 & 0.635 & 0.557 \\
\hline
\end{tabular}


Pinicola enucleator

Pica pica/Pica hudsonia

\begin{tabular}{rrrrrrrr}
$v_{2}$ & & 0.094 & 0.109 & 0.210 & 0.332 & 0.537 & 0.526 \\
$v_{2}$ & & 0.182 & 0.282 & 0.308 & 0.391 & 0.566 & 1.702 \\
$T$ & 7 & 6 & 5 & 4 & 3 & 2 & 1 \\
$T$ & & 0.329 & 0.310 & 0.358 & 0.282 & 0.434 & 0.632 \\
$T$ & & & 0.095 & 0.128 & 0.213 & 0.207 & 0.369 \\
$T$ & 0.100 & 0.153 & 0.097 & 0.111 & 0.164 & 0.194 & 0.315 \\
$T$ & & 0.052 & 0.066 & 0.110 & 0.196 & 0.350 & 0.322 \\
$T$ & 0.138 & 0.149 & 0.208 & 0.261 & 0.275 & 1.006 & 2.508 \\
$T$ & & 0.056 & 0.118 & 0.250 & 0.178 & 0.284 & 0.408 \\
$T$ & & 0.183 & 0.291 & 0.437 & 0.578 & 0.848 & 0.396 \\
& & 0.193 & 0.265 & 0.350 & 0.444 & 0.608 & 0.673 \\
$\Theta$ & 7 & 6 & 5 & 4 & 3 & 2 & 1 \\
$\Theta$ & & 0.262 & 0.295 & 0.296 & 0.264 & 0.333 & 0.490 \\
$\Theta$ & & & 0.077 & 0.094 & 0.153 & 0.126 & 0.237 \\
$\Theta$ & 0.068 & 0.046 & 0.052 & 0.059 & 0.083 & 0.094 & 0.153 \\
$\Theta$ & & 0.035 & 0.042 & 0.067 & 0.113 & 0.173 & 0.231 \\
$\Theta$ & 0.337 & 0.283 & 0.280 & 0.338 & 0.395 & 0.608 & 0.670 \\
$\Theta$ & & 0.030 & 0.070 & 0.158 & 0.108 & 0.126 & 0.242 \\
$\Theta$ & & 0.060 & 0.118 & 0.186 & 0.224 & 0.284 & 0.298 \\
& & 0.123 & 0.161 & 0.218 & 0.278 & 0.386 & 0.463 \\
\hline
\end{tabular}

4

Clangula hyemalis

Anas crecca

Mareca penelope/M. americana

Numenius phaeopus

Tringa brevipes/T. incana

Luscinia svecica

Pinicola enucleator

Pica pica/Pica hudsonia

Clangula hyemalis

Anas crecca

Mareca penelope/M. americana

Numenius phaeopus

Tringa brevipes/T. incana

Luscinia svecica

Pinicola enucleator

0.123

0.161

0.218

0.463 


\section{Table 4 (on next page)}

\section{Regressions}

Linear regression equations for scaled root mean square error (SRMSE) for each parameter (from Table 3), summarizing how accuracy declines with diminished sample sizes.

Parameters are migration $(m)$, effective population size $\left(v_{1}\right.$ and $\left.v_{2}\right)$, time since divergence $(T)$, and $\Theta$ (defined as $4 N_{\text {ret }} \mu$, where $N_{\text {ref }}$ is ancestral population size and $\mu$ is mutation rate per generation). Note that these are based on SMRSE values (to enable among-lineage comparisons). Thus, $y$ in the regression equation $y=m x+b$ is SMRSE for that particular demographic variable ( $m$ is slope, $x$ is $N$, and $b$ is the $y$ intercept). 
1 Table 4: Linear regression equations for scaled root mean square error (SRMSE) for each parameter

2 (from Table 3), summarizing how accuracy declines with diminished sample sizes. Parameters are

3 migration $(m)$, effective population size $\left(v_{1}\right.$ and $\left.v_{2}\right)$, time since split $(T)$, and $\Theta$ (defined as $4 N_{\text {ref }} \mu$, where

$4 \quad N_{\text {ref }}$ is ancestral population size and $\mu$ is mutation rate per generation). Note that these are based on

5 SMRSE values (to enable among-lineage comparisons). Thus, $y$ in the regression equation $y=m x+b$ is

6 SMRSE for that particular demographic variable ( $m$ is slope, $x$ is $N$, and $b$ is the $y$ intercept).

7

\begin{tabular}{llrr} 
SMRSE for variable & Regression equation $(\mathbf{y}=\mathbf{m} \mathbf{x}+\mathbf{b})$ & \multicolumn{1}{c}{$\mathbf{r}^{\mathbf{2}}$} & \multicolumn{1}{c}{$\boldsymbol{P}$} \\
\hline$m^{a}$ & $\mathrm{y}=-0.00858 * N+0.87714$ & 0.413 & 0.0007 \\
$v_{1}$ & $\mathrm{y}=-0.17563 * N+1.05063$ & 0.117 & 0.0156 \\
$v_{2}$ & $\mathrm{y}=-0.16171 * N+0.97351$ & 0.305 & 0.00004 \\
$T$ & $\mathrm{y}=-0.10045 * N+0.70147$ & 0.237 & 0.0004 \\
$\Theta$ & $\mathrm{y}=-0.03825 * N+0.34738$ & 0.220 & 0.0007 \\
\hline
\end{tabular}

$8{ }^{a}$ Note that this is for the low-divergence group only. 


\section{Figure 1}

\section{Parameter estimates}

Parameter estimates of effective population size $\left(v_{1}\right.$ and $\left.v_{2}\right)$, time since divergence $(T)$, migration $(m)$, and $\Theta$ for selected lineages (parameters are raw, unconverted values directly from $\delta a \delta i$ analyses) . 

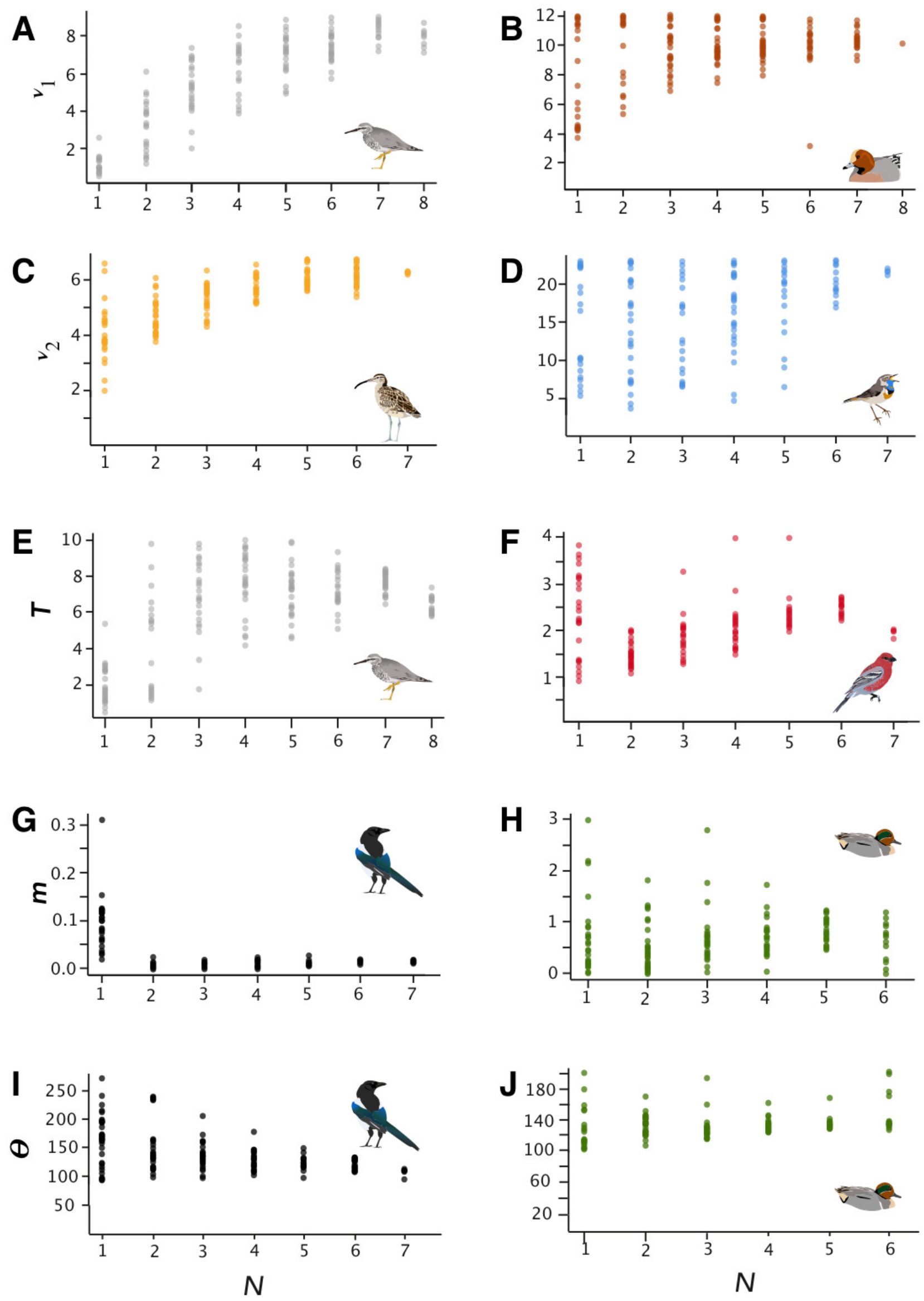
Figure 2

SRMSE values

SRMSE values for demographic parameters estimated at various sample sizes in this study, indicating how estimates decrease in accuracy with smaller sample sizes. Pairwise comparisons within each lineage are coded at lower right. Note that vertical scales are different in each panel. 

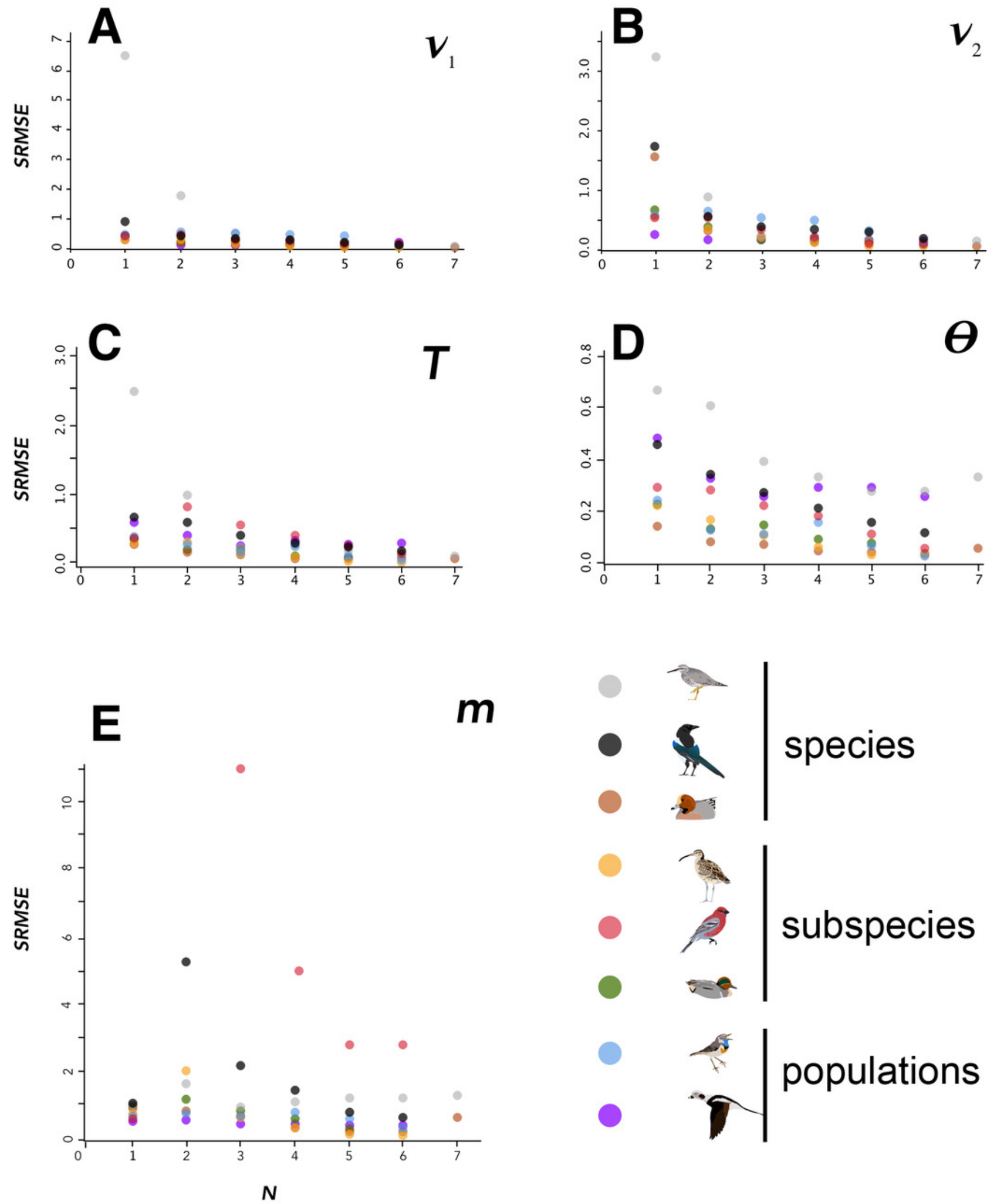

m

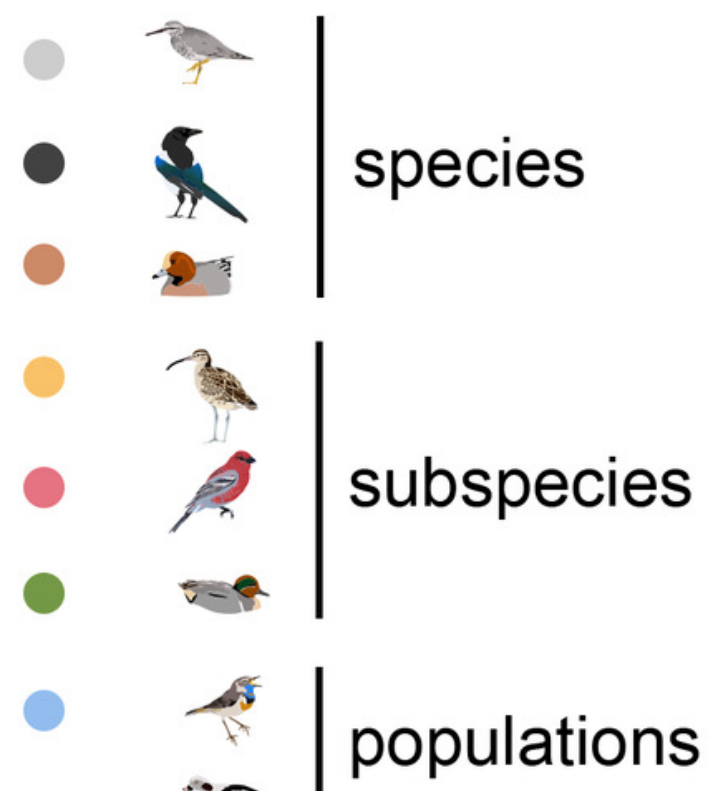

